\title{
DEMYSTIFYING POWER IN COMMUNITY DEVELOPMENT PRACTICE
}

\author{
Anif Fatma Chawa* \\ Department of Sociology, Faculty of Social and Political Sciences, \\ Universitas Brawijaya, Jl. Veteran, Malang 65145, Indonesia \\ E-mail: anif_chawa@ub.ac.id \\ Marty Grace** \\ College of Art, Victoria University, \\ PO Box 14428, Melbourne, Victoria 8001, Australia \\ E-mail: Marty.Grace@vu.edu.au
}

Published online: 15 January 2019

To cite this article: Chawa, A. F. and Grace, M. 2019. Demystifying power in community development practice. International Journal of Asia Pacific Studies 15 (1): 153-181, https://doi.org/10.21315/ijaps2019.15.1.6

To link to this article: https://doi.org/10.21315/ijaps2019.15.1.6

\begin{abstract}
This article seeks to understand the issue of power as the root-concept of empowerment as the main objective of community development practices. The empowerment objective requires distribution of power to powerless people or community. This could be problematic if community development practitioners already have power over communities, including a mining company. This study examines to what extent the idea of empowerment could be embraced by the mining company in the implementation of the community development programmes as a part of its Corporate Social Responsibility (CSR) framework. This study also exhibits a model or mechanism by which the distribution of power can be conducted in community development practices. The study was conducted in a mining project located in a West Sumbawa district, Sumbawa Island, Indonesia. This study found that the company, in the powerful position, has used the power to secure its operations. It is shown from the tension between two different agendas of the mining company, including the production/commercial framework (with its primary focus on profits) and development agendas, emerged in the implementation of its community development programmes. The mining company has distributed its community development programmes to placate the protest actions of the local


community. This has resulted in unintended impacts of these programmes including financial dependency and resistance of the local community to the company. This study, however, found the fact that the power could be distributed by employing an ongoing and comprehensive assistance model to increase capacity of the community to have control on their own development programmes. This model, in a limited way, has succeeded to empower the community in conducting their own development programmes independently.

Keywords: Power, mining company, community development, CSR, empowerment

\section{INTRODUCTION}

Mining is one of the world's major industrial sectors, which in some cases holds a dominant position in the socioeconomic development of many nations. It is also rapidly expanding to remote areas of the world due to the liberalisation of investment regimes in developing countries and the transition in economies (Yakovleva 2005: 1). On the other hand, this kind of industry has also been criticised for giving rise to various negative impacts in many different countries, for example in Russia (Rosenthal 2002; Yakovleva 2005), Suriname (MacKay 2002), the Philippines (Martin and Newell 2008), Ghana (Korsah-Brown 2002), and Indonesia (Leith 1993; Robinson 1986; Larmer 2009; Welker 2009). These impacts include environmental degradation, conflicts between the mining companies and communities, the destruction of local economies and culture, and human rights violations.

Mining industries are required to be responsible for those related negative impacts, one of the ways is by conducting Corporate Social Responsibility (CSR). The expectation of CSR is that business communities have a new role as social agents toward their internal and external environments including the society or community in the local area (Wartick and Wood 1998; Wood 1994). This role adds to the central role of businesses, which is to perform as an economic institution through obtaining profits and increasing production. As social agents, businesses are seen as socially responsible for bringing wealth to the community. This perspective is supported by ethical arguments highlighting the issues concerning the negative impacts of business or corporate activities on the community. Thus, CSR is particularly necessary to be a part of mining industry programmes, because they have significant effects upon economic, social and environmental dimensions, and are viewed as one of the most damaging and dangerous activities of the industrial sector (Yakovleva 2005: 19). 
In practice, CSR policies have resulted in expansion of the business involvement in development activities for communities (Newell and Frynas 2007). Therefore, "many mining companies now use the language of community development and participation as a part of sustainable development and CSR framework" (Kemp 2010: 199). Business or private sectors are expected to address various development problems, such as poverty; social exclusion based on gender, race, ethnicity and class inequality; social justice and other development challenges. The role of businesses in development has been grounded in the sociopolitical governance approach which assumes that community development is the responsibility of all social actors including non-profit, public and private sectors (Moon 2002).

However, some scholars argue that there is still a lack of evidence that these development responsibilities have delivered benefits to the local communities (Newell and Frynas 2007). There has been skepticism about the involvement of business in the development programmes since the objective to achieve greater production and profits is more dominant than the aim of contributing to the development programmes for community betterment through CSR (Blowfield 2004; Cragg 2002; Fox 2004; Hamann 2003; Harcourt 2004; Kapelus 2002; Kemp 2010; Leisinger 2007; Newell and Frynas 2007; Utting 2007; Wartick and Wood 1998). It has been claimed that business involvement in the development programmes has been purely for public relation reasons and as tokenism gestures rather than genuine contributions towards poverty reduction and human development. All these theorists are pessimistic about the potential contribution of CSR and the capability of business to reconcile its main objective of profit with the obligation to be responsible in the development programmes.

Several studies show that there are many issues related to the implementation of the community development programmes in the mining industries in Indonesia (Setiawan and Ginting 2008; Tahajuddin et al. 2006; Leith 1993; Welker 2007, 2009, 2012; Larmer 2009). Among these studies was a study conducted in a mining industry area located in West Sumbawa District, Sumbawa Island, West Nusa Tenggara Province of Indonesia, where this research was also conducted (Larmer 2009; Welker 2009, 2011, 2012). There is some evidence that these industries have conducted the community development programmes primarily for pragmatic or instrumental reasons. Mining companies have delivered the community development programmes as a strategy to avoid conflict or protests from the local community which would affect the mining operations. In general, the mining companies have established short-term and unsustainable community development programmes 
that do not necessarily have community empowerment as an essential part of their implementation. This has raised several questions which become targets of this study. First to what extent the mining industries embrace the idea of empowerment as an objective of their community development programmes. Second, this study exhibits a model or mechanism of which the distribution of power can be conducted in the community development practices.

\section{THE "MYTH" OF POWER IN COMMUNITY DEVELOPMENT PRACTICES}

Whatever different definitions of the community development are, most exponents share the idea that community development allows people or a community to take control of their own development processes, i.e., the processes which have an impact on their life (Ife 2013; Kenny 2006: Korten 1987; Chambers 1993). These people or communities are groups who can be considered as poor, disadvantaged, oppressed or exploited in relation to human rights and social justice issues (Kenny 2006; Ife 2013; Chambers 1993). Community development practitioners focus on increasing the capacity of the local community, so they have power and control in designing, conducting and identifying problems which occur and finding the solutions to these problems; this is known as the empowerment process (Bhattacharyya 2004; Kenny 2006; Swanepoel dan De Beer 2006). Ife (2013: 63) states that "empowerment aims to increase the power of the disadvantaged; it is about giving power to individuals or groups, allowing them to take power into their hands, redistributing power from the haves to the have not and so on." Ife (2013: 277) continues to explain that community development practitioners have been challenged to provide people or a community with "the resources, opportunities, vocabulary, knowledge, and skills to increase their capacity to determine their own future, and to participate in and affect the life of their community." To pursue the community empowerment objective, community development must adopt self-help principles and a bottom-up approach, which require community participation in conducting development programmes (Kenny 2006; Larrison 2002).

Larrison (2002) identifies two approaches or models to implement community development programmes. They are the top-down and bottom-up models which have different methodologies for conducting the community development programmes. Macdonald (1995) states that the top-down model is structured around the use of professional leadership provided by external 
resources that plan, implement and evaluate development programmes. This means that the changes of perception, behaviours and ultimately, standard of living of a community can occur with the intervention of external leadership. On the other hand, the bottom-up model focuses on how people within communities can direct their own development processes (Larrison 2002). It proposes that the participation of communities, which will develop opportunities to learn, and the sense of empowerment that comes with that knowledge, are constructive to obtain the goals of the community development.

Related to community development practices, the study of power is imperative as it has a community empowerment objective in its implementation (Hustedde and Ganowicz 2002; Kenny 2006). However, the complex and various concepts of power have been assumed to become the main reason why community development practitioners are reluctant to give much attention on the issue of power. There are many social and political theorists who focus their studies on power. In terms of the community development practices, Korten (1987) states that a generative dimension of power is more imperative rather than distributive as it only focuses on the capacity of individuals to influence others. Meanwhile, the generative dimension of power requires power holders to release some of their power to the powerless. This means that the increasing power of the powerless people will reduce the power of the power holders. Korten's notion of power is in line with Marxist point of view about power which can be treated as a "commodity," which can be possessed by a person, groups of people and state. It indicates that power as a commodity "can be traded or given away, or transferred from one person or group to another" (Fook 2012: 56). Consequently, power in the Marxist perspective sometimes has been perceived in a negative way (DuBois 1991; Smart 2002). "People or groups who possess more power tend to use this power as a repressive force that limits, controls, forbids, masks, withdraws, punishes, excludes and subjugates others who have less" (DuBois 1991: 5). On the other hand, people or groups who have less power will use a repressive force to get the same power or position as possessed by groups who have more power (DuBois 1991). There might be several ways by which communities are able to respond to oppression or domination. Rather than seeing the repressive force, Scott (1985) shows every-day forms of resistance which is less visible rather than the repressive force, for instance foot-dragging, evasion, false compliance, pilfering, feigned ignorance, slander and sabotage.

In the context of community development practices, Fook (2012) states that power in Marx or the conventional perspective could be problematic for the process of empowerment in several ways. First, the empowerment process 
in modernist notions is "always at the expense of one group or person towards another" (Fook 2012: 56). This means that a person or group who has more power should give some of their power to empower others who have less power. Thus, the process of empowerment for a person or group will cause disempowerment of others. Second, the process of empowerment is about striving for equality; however, the concept of equality is often oversimplified as sameness. The empowerment processes in this perspective requires all people and groups to become the same. This perception might ignore inequity and heterogeneity within communities (Berner and Phillips 2005). Third, Fook (2012) points out that modernist notions of power tend to split people and groups into two oppositional relations, the powerful and powerless. In this binary opposition, the process of empowerment seems unachievable.

Some scholars strongly argue that the issue of power has association with the way by which people or community should participate in the development processes (Arnstein 1969; Bendell 2005; Onyx and Benton 1995). Without power, the participation process becomes empty and ineffective (Arnstein 1969; Swanepoel and De Beer 2000). This has raised several questions including the kind of participation and the extent to which communities should be involved in the development processes. Some scholars state that participation mean that people or community should be included to all steps of development processes which are: identifying the needs, options or strategies, decision, or choice of action; defining the problem to be solved and how to solve it; and mobilising resources, including their knowledge/ material and the action itself (McArdle 1989; Bhattacharyya 2004; Berner and Philips 2005).

Arnstein (1969) argues further that a high level of participation would be achieved if the people are given power in decision making processes. $\mathrm{He}$ describes citizen participation at three primary levels: (1) non-participation, involving therapy and manipulation; (2) tokenism, encompassing information, consultation and placation; and (3) citizen power, involving partnership, delegated power and citizen control. On the first level, therapy and manipulation are the non-participatory methods contrived by some developers to substitute for genuine participation. Their real objective is not to enable people to participate in planning or conducting programmes, but rather to enable powerholders to educate or cure the participants. On the second level, tokenism: although those without power can hear and have a voice, they cannot ensure that their views will be heeded by the powerful. Here, placation is simply a higher level of tokenism with ground rules that allow have-nots to advice, but retain the rights of power-holders to decide. The third level of citizen 
power involves a partnership process that enables citizens to negotiate and engage in trade-offs with the traditional power holders. This is the highest level of participation, delegating power and citizen control with have-not citizens achieving the majority of decision-making seats and enabling them to have full managerial power. By dividing the citizen participation into several categories, Arnstein (1969) highlights the fundamental point that participation without redistribution of power is an empty and frustrating process for relatively powerless people.

In practice, however, redistribution of power could be challenging in term of several points which are how community development practitioners give some of their power to community, or are they willing to release some of this power to the community. Another crucial question is concerning how the community development practitioners who already have "power over" a local community, such as statutory authorities, financially powerful organisations and the business community, including mining companies, can engage in empowerment. All these questions show that a problem of power have become an unsolvable problem and challenged community development practitioners in achieving a community empowerment objective. This article will show how the problem of power could be demystified based on two instances of the community development practices.

\section{RESEARCH SITE}

This study was conducted in the second largest foreign mining company in Indonesia, located on West Sumbawa District, Sumbawa Island and West Nusa Tenggara Province. This company has been operating in two different social and political circumstances: the new order (1966-1998) and democratic reform (post 1998) periods. The exploration and construction stages of this mining company were conducted in the new order period. The operational stage commenced in 1999/2000 when the democratic reform period began and would be ceased on 2025/2027. These two periods involved different systems of mining regulation: the centralisation system in the new order and the decentralisation system in the democratic reform period. In the democratic reform period, business institutions in Indonesia encountered the instability of social, economic and political issues which occurred due to the transformation process from the new order to the democratic reform period (Soelistijo 2010). This social and political background has influenced the way in which the mining company has conducted the community development programmes and built its relationships with the local community and local government. 
The closest areas to mining operation are Maluk, Sekongkang and Jereweh sub districts, described by the mining company as the mining circumference areas. The mining company has conducted its community development programmes most intensively in these sub districts which have been assumed suffering from the worst negative impacts of the mining operation. Before mining was established, the local people described these sub districts as a small village in a remote area and used to ride a horse and other traditional form of transport (name cidomo). Most of the local communities made their living from traditional agriculture, gardening and raising animals. Occasionally, they went to the forest to hunt for animals, cut timbers and gather the wild honey-which is famous in this area. Local communities lived at a subsistence level, consuming their harvest to fulfil their basic needs rather than for commercial reasons. The local communities had a low education level due to the fact that their district lacked educational infrastructure. Most of the population was illiterate with approximately 90 percent of the population educated only to the primary school level. The low education level and the lack of specific skills of the local community members had hampered them to work as the mining company's employees. This issue has become the main source of conflict affecting the relationship between the mining company and the local community in the mining circumference area.

The existence of a large mining industry attracted many people from other regions outside Sumbawa Island (Badan Perencanaan dan Pembangunan Daerah [BAPPEDA] Kabupaten Sumbawa Barat 2008). This has transformed West Sumbawa District from a very remote area to a busy, rich and wealthy district on Sumbawa Island. Data from an observation show that Maluk and Jereweh have now become the home of thousands of mining company employees who chose to live in these sub districts, instead of in the town site: a little town that has been built by the mining company full of facilities and services for their employees. Maluk sub district moreover has become the urban centre of the mining circumference area. Many local community members and people who came from outside West Sumbawa district built stalls, cafés, restaurants, hotels, dormitories, shops and supermarkets in this sub district. This small city is busy for 24 hours a day to serve the needs of thousands of employees. The interaction between the local community members and these employees, however, has caused various negative impacts including a change in the way the local communities live: for instance, their life style, norms, customs, ethics and morals. This study found other negative impacts of mining operations including economic inflation, conflict between 
the mining company and the local community related to the employee recruitment process and environment degradation, mainly deforestation and water pollution problems.

\section{RESEARCH METHOD}

To fully capture the complexity of the problems and issues of the study, a single case study approach was implemented to avoid the limitation of more than one case study and survey method. Data were collected by employing semistructured interviews, review of documents and observation. All supporting data (i.e., mining legislation; research studies conducted by NGOs; and mining company's documents such as environment impact analyses, community development strategic planning, brochures, leaflets and internal publications) were examined.

Forty-two informants were selected based on their involvements and responsibilities in relation to the mining company's community development programmes. To select the informants, the researchers employed two sampling strategies: purposive sampling and snowball sampling. The purposive sampling was used to gather six informants from the government, both legislative and executive. They were from the provincial government, BAPPEDA or Local Planning Agency, and two majors from the West Sumbawa and Sumbawa districts. Sumbawa is the former district where the mining company was located. In 2003, this district was divided into two districts: Sumbawa and West Sumbawa districts. Now, the mining company is administratively located in the West Sumbawa district. The snowball sampling was employed to gather nine informants from the mining company, 21 from the local community, and six from the local NGOs. The researchers identified a key informant from the mining company. This informant then provided the information related to other informants who were connected to the mining company's community development programmes. These informants were chosen based on their responsibility or their contribution to the implementation of community development programmes. Based on this information, the researchers were able to choose the informants from the local NGOs who had been involved in the mining company's community development.

Informants from the local community members were collected in different ways. Local community members involved in the mining company's development programmes were chosen based on the information gathered from the local NGOs and two community development foundations: Yayasan 
Pengembangan Ekonomi Sumbawa Barat (YPESB) and Yayasan Olat Perigi (YOP). Meanwhile, the local community members not involved in the mining company's community development programmes were gathered based on the information from a local community leader. The person who was considered as the local community leader in this study was a person whose family had lived in this mining area already for many generations, even before the mining industry started operating. From this local community leader, the researcher obtained referrals to other local community members.

This study involved field research which required approximately four months in 2010. During the data gathering process, the researcher had an opportunity to live in two kinds of environment, both inside and outside the mining company. For several weeks, the researcher had a chance to stay in the company's town-site. For the remaining weeks, the researcher stayed in the villages in the vicinity of the mining area. The researcher built a relationship with the local communities and got involved in their everyday life. When staying with the local communities, the researcher was able to have informal conversation and observe the problems related to social, cultural, economic and environmental impacts of mining operations on the local communities.

\section{RESEARCH FINDINGS}

This study found that the mining company in West Sumbawa establishes two foundations to deliver its community development programmes which are YOP and YPESB. The establishment of these foundations is based on a main reason: they will be able to continue to undertake the community development programmes after the mine is closed, as described in the interview excerpted below:

The mining company won't be here forever. From the beginning, the mining company has realised that there should be a foundation to continue conducting community development programmes after the mine closure. - Ardy, a Community Development Division staff member

The interviewee explains that the mining company realised that its operation would finish at a certain time. Therefore, there should be an institution or foundation that would continue the implementation of community development after the mine is closed. The mining company has installed several employees to become the supervisors and "connectors" who assist its foundations in 
undertaking their community development programmes. In addition, they also have the task of monitoring the effectiveness of the budget provided by the mining company for both foundations to undertake their community development programmes. YOP and YPESB have delivered the community development programs to the local community members who live both in and outside the mining circumference areas. It should be noted, however, that there are differences between those two foundations regarding their relationship to the mining company and their practices in terms of community development programmes.

\section{YPESB}

The mining company established YPESB as the first community development foundation. This foundation is always associated with the mining company's foundation based on two reasons. First, YPESB was established by the mining company previously at the construction stage (in 1998). At that time, all of YPESB community development workers were the employees of the mining company. The "double" role of these employees - as the community development workers of YPESB and the mining company employees - gave rise to administration and financial problems. As a result, the mining company closed YPESB temporarily in 2003. The mining company reactivated the "new" YPESB in 2005. In contrast to the former YPESB, the "new" YPESB also recruited local community members as its community development workers. The role of the mining company can be shown by the inclusion of its employee as the supervisor or manager of YPESB.

Second, both previous and the new YPESBs always adopt a top-down approach in conducting its local business development as explained by Ardy:

The two foundations represent two approaches, YOP (another mining company's foundation) employs the bottom-up approach; another foundation (YPESB) adopts the top-down approach.

The informant explains that YPESB delivers its development programmes, mainly local business programmes, by employing a top-down approach as illustrated in Figure 1: 


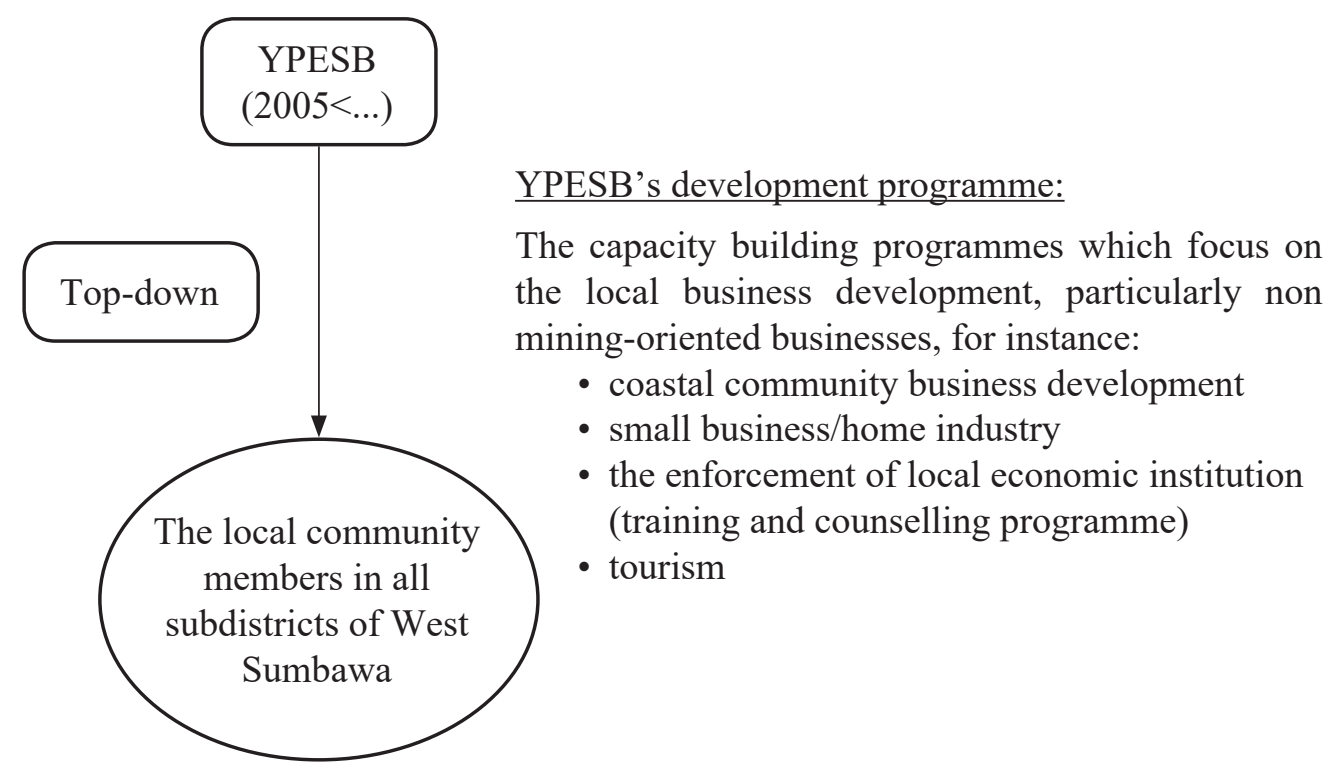

Figure 1: YPESB's community development model (source: compiled from the interviews).

By employing a top-down approach, YPESB establishes three or four kinds of local businesses development programmes per year. These businesses explore the local economic potential of West Sumbawa that is rich in natural resources and has potential for tourism and coastal economic development (such as seaweed cultivation) and other kinds of local businesses (such as Aloe Vera and mushroom businesses). YPESB has established these kinds of businesses since they are more sustainable and can be managed by the local communities, even after the closure of the mine. These businesses involve the mining company as the funder or investor for the business activities. In addition, YPESB has facilitated the members of the local community who want to develop their small businesses or home industries by providing training and counselling programmes, and introducing them to financial institutions, such as the local bank, to obtain funding for developing their businesses.

\section{YOP}

In contrast to YPESB, YOP has been "appointed" to be the local community's foundation. This can be shown from the involvement of three parties consisting of the local community, local government and mining company in establishing this foundation in 1999. An interviewee illustrates this as follows: 
YOP and YPESB are different because YOP was constituted for the local community. Therefore, all YOP's community development workers were recruited from the local community members. - Joko, a Community Development Division staff member

The preceding interview excerpts illustrate the differences between YOP and YPESB. YPESB is closely associated with the mining company foundation due to the fact that the company had a dominant role in establishing both the former and the new YPESB. In contrast, the establishment of YOP has involved the local community members. Moreover, all YOP's workers are the local community members and local NGOs.

YOP is also different from YPESB in terms of the model or approach to deliver the development programmes, and the kinds of development programmes which are distributed to the local communities. While YPESB adopts a top-down approach, YOP employs a bottom-up approach, which provides opportunities for the local community members to establish their development programmes. The main programme of YOP is a revolving fund programme which becomes a potential funding for the local community members to establish their own development programmes, as illustrated in Figure 2:

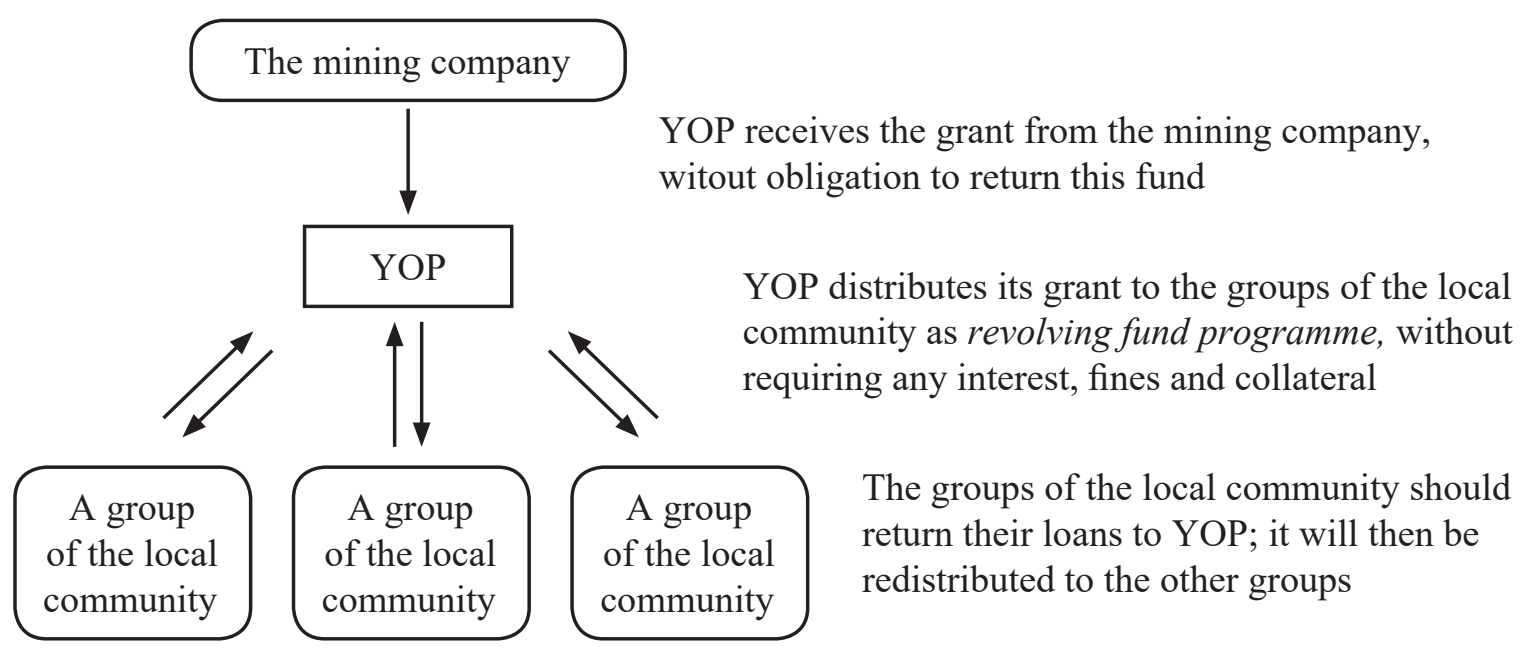

Figure 2: YOP's revolving fund programme (source: compiled from the interviews).

Figure 2 shows how YOP distributes its revolving fund programme. In this programme, YOP lends money to the local communities to conduct their development programmes. The local community members are required to fill an application form with a detailed explanation of their development programmes and the budget they would need for the programmes' implementation. In this application form, YOP already stipulates the amount of budget or loan for 
the development programmes' implementation, ranging from Rp 250,000

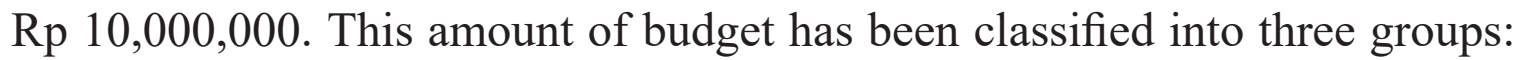
individuals, groups and koperasi (cooperative). In the application form, YOP also mentions various kinds or options of development programmes which can be proposed or choosen by the local communities, for instance: the kinds of animal; the kinds of agricultural equipments (hand tractors, water pumps, and winding machines); the kinds of agricultural programmes (rice, fruit and vegetables, fertiliser and others); and car and motorcycle repairing businesess. The application form method requires a cross check process to evaluate the feasibility of the development programme that has been proposed by the local community member. Based on the feasibility of the development programme, YOP will evaluate the applicants who should be accomodated in its revolving fund programme.

The previous discussion illustrates that YOP and YPESB are also different in regard to the kinds of development programmes they deliver to the community. YPESB concerns more on the increasing capacity of the local community members to undertake their businesses. YOP, in contrast, provides infrastructure programmes and funds which are needed in conducting development programmes.

In revolving fund programme, the local community members who obtain the loans should return their loans to YOP; YOP will then redistribute these loans to other local community members. In addition, YOP has provided this revolving fund programme without any interest, fines or collateral to the local communities. The mining company has been the main funder for this programme by allocating about USD 650 per three months regularly for YOP (Mining Company 2005). This money has been given as a grant for YOP. This means that YOP does not have an obligation to return the fund to the mining company. YOP can continue to use this grant to conduct the community development programmes even after the mine is closed. In addition, YOP also uses the fund from the mining company to pay the salary of its community development workers.

The mining company has placed its staff as a "connector" between the mining company and YOP, as illustrated in the following interview excerpt:

The mining company has assigned me to "watch" the YOP activities, whether they have been done correctly or not according to the budget they get from the company ... we also have to audit this foundation ... that is my function. - Andi, a Community Relations Division staff member 
Andi explains that the mining company has appointed him as a "connector" between YOP and the mining company. His job involves "watching" YOP activities, particularly in which YOP uses the budget from the mining company. Andi goes on to explain that the mining company audits or evaluates these YOP activities regularly.

\section{THE DIFFERENT OUTCOMES OF YOP AND YPESB'S COMMUNITY DEVELOPMENT PROGRAMMES}

This study found that the different approaches which have been adopted by YOP and YPESB to conduct their development programmes have resulted in different outcomes including financial dependency, resistance and empowerment of the local community.

\section{Financial Dependency, Frustration and Resistance of the Local Community on the Mining Company}

This study found that most of YOP's revolving fund programmes have caused dependency of the local community on the mining company. This is related to the selection or evaluation of the local community members who will receive YOP's revolving fund programmes. The local communities have claimed that in this process YOP gives priority to its own workers and to other particular groups of the local communities. These particular groups are the problematic group and the local community members who have a close relationship with YOP's workers. The problematic groups refers in a part to a group of local community members who often make a lot of commotion in their bids to obtain loans from YOP. Other problematic groups include local community members who protest against the mining company, particularly in relation to employment recruitment issues. These issues concerning the problematic groups are discussed by these interviewees:

One of the problems is related to special "orders" from the mining company ... so it is clear that YOP is not an independent institution. For instance, there is a text message from the Community Relation division to YOP, "There is a demonstration, please give the fund to these people." - Tony, a local council member of West Sumbawa

The interview result explains how YOP has been pressured to accommodate the problematic groups in its revolving fund programmes. These groups have protested to the mining company for employee recruitment opportunities. 
To accommodate these groups, the mining company has sent them to obtain the money/loan from YOP's revolving fund programmes. The mining company requires this kind of solution to settle the protests from the local communities. This is why YOP has been associated with particular roles, for instance, as the "fire brigade" or "panadol" to calm or address the riots and protests of members of the local community against the mining company. These negative reactions of the local communities potentially threaten the mining operation. Therefore, YOP has given priority to these groups in relation to receiving loans from its revolving fund programmes.

The financial approach that is conducted by YOP to overcome the relational problems of the mining company with the local communities has impacted on several issues including the unrepaid debt issue, the creation of money orientation character, and the resistance of the local communities. Regarding the unrepaid debt issue, there are a number of groups from the local communities who have failed to return their loans to YOP due to several reasons. Firstly, these people spent or sold the fund, agriculture equipments and animals that they obtained from YOP to fulfill their basic needs, as illustrated by Andi:

There are local community members who have succeeded in the revolving fund programme, but there are others who do not intend to return their loans ... they use this money to fulfill the family needs.

Secondly, some local community members have assumed that they do not need to return their loans. They argue that the revolving fund programme is grants or gifts from the mining company; this means they do not need to return the money which they have obtained from the revolving programme. This has been explained, again by Andi:

The obstacle of the revolving programme is, the local community members assume that the loans which they obtained from the revolving fund programme is a grant from the mining company. They argue that there are many people who have the same opinion.

The third reason that local community members decide not to return their loans is because they have seen and then copy what other members have done, as illustrated by this interviewee:

"Why should I return this money while the other members should not?" The local community members often say. - Ardy, a Community Development Division staff member 
This comment demonstrates resistance of some local community members by refusing to return the money which they borrowed from the revolving fund programmes. This refusal is triggered by the different treatment in YOP's revolving fund programmes. YOP has privileged the problematic groups who are against the mining company by absolving them or not forcing these groups to return their loans to YOP. This privilege has led to protests from other local community members. They express this protest by asking for the same treatment as the problematic groups and refusing to return the loans to YOP. This has led to the "unrepaid debt" issue in the YOP's revolving fund programmes.

Another resistance has been shown by the local community's members who refuse to participate in the community development programmes. These non-participating community members believe that the community development programmes will not give them many benefits from the mining operation. An interviewee from the local NGO who focuses on the agricultural sector has illustrated this problem:

A mining company employee who lives in front of my house gets a salary Rp 11,000,000 per month. Although he has lower skill than us, he has higher income than us. Meanwhile, as a farmer, we should go to work at the early morning and go home at the very late afternoon, but we get nothing... that is why many local community members do not want to participate in the agricultural programme and keep expecting that one day they can be recruited as a mining company employee... I often said to them, "how many years more will the mining company be operating, have you prepared yourself?" - Deni, a member of an NGO for the agricultural programme

Deni in an interview explains the reason why local community members refuse to participate in the community development programme, particularly in the agricultural sector programme. Deni complains that those members have made a comparison that they will not get higher income from the agricultural sector, not as much income as if they work as an employee in the mining company. Therefore, they still have an expectation to be recruited as a mining company employee and refuse to participate in the agricultural programmes.

It can be argued that the resistance from the local community emerges due to the fact that they want to ensure that some benefits of the mining operation will go to them. The local communities seem to doubt that they could derive these benefits from the community development programmes. They doubt that their participation in the community development programmes will 
bring about economic betterment. Furthermore, the local communities have seen that there are many problems in the implementation of these programmes which have given rise to their frustration and resistance to participate in the mining company's community development programmes.

Furthermore, the local communities have seen that there are many problems in the implementation of these programmes which have given rise to their frustration and resistance to participating. The financial approach of YOP's development programme has been blamed for causing the people in the local communities to focus more on money. Many of the local community members are only willing to participate in the development programmes so long as they are able to earn money or other benefits from them. This moneyorientation character of the local communities has weakened their participation in the development programmes, as illustrated in this interview:

The local community members protested, the mining company gave them money, the local community members protested, the mining company gave them money. Finally, they have become "a spoilt community." I assume that the mining company might not have realised its mistake. - Wawan, a Kelompok Swadaya Masyarakat (KSM) member (a revolving fund programme related to the agriculture programme which has been conducted mostly by groups of the farmers' wives)

We realise that the local community has participated in the community development programmes. But we also found that there is less participation if they won't get any money from the community development programme's implementation. - Joko, a Community Development Division staff member

This orientation toward money is not in the traditional nature of the local community character. An interviewee explains that this change in character has been caused by the money-focused or the financial approach which has been pursued by the mining company to address its relational problems with the local communities. This led to the creation of this money-oriented character which further becomes a major factor in hindering the achievement of the community empowerment objective.

\section{Empowerment of the Local Community}

The previous discussion shows that the implementation of YOP's revolving programme has resulted in several unintended impacts of community 
development programmes including financial dependency and resistance of the local community. Paradoxically, one of the mining company's community development foundations, YPESB has initiated such a high level of the local community participation. It incorporated four aspects: it was well planned by the mining company (top-down); it accommodated the participation of the local community; it provided an ongoing resources and assistance which are needed by the local community in conducting their community development programmes; and was conducted by community development practitioners who have experiences or capability in conducting this approach.

By using a top-down approach, YPESB established several local business programmes which can be chosen by the local community members for their development programmes. YPESB, moreover, continues to give comprehensive and ongoing assistance to the local community members by which their capacity and skills can be increased. This process is described by an interviewee:

YPESB gives comprehensive assistance to the local community for a year until they become successful. For example, we have conducted an Aloe Vera business. We assist the local community members in how to cultivate Aloe Vera, how to make various kinds of food products made from Aloe Vera such as jelly and jelly drinks, and the packaging of these products. Then we assist these members to make a contract with other business institutions to sell their product. - Totok, an YPESB community development worker

We deliver a business programme to the local community. Then we connect them with the bank or other local government institutions because we are not a bank that could continually give money to the local community - Ardy, Community Development Division staff member

The interviewee describes an ongoing assistance which has been conducted by YPESB. For instance, in the Aloe Vera business programme, YPESB gives full assistance to its members from the beginning of the process: the cultivation and provision of the Aloe Vera seedlings; the processing of Aloe Vera into various food and drink products; the packaging of these products; and finding the network and the market for these members so they can sell their product to consumers. YPESB provides additional support: for instance, providing various training programmes, finding financial resources and temporarily paying employees salary needed in all these processes. By giving ongoing assistance, YPESB attempts to empower the local community step-by-step 
so they will have power and control and enhance their sense of belonging in undertaking these local business programmes.

YPESB offers its comprehensive support and assistance until these members become success and independence in managing these businesses independently. This study found that several local community members involved in the YPESB's local business programmes have been successful and independent in conducting their businesses. They state that YPESB often provides them with training programmes to increase the quality of their products:

In the beginning, YPESB funded all the activities in this business including paying the salary for the workers. After the local community members businesses become successful and earn a profit from its production, they have to pay the workers by themselves. However, YPESB does not abandon this business; it still keeps providing training if needed. - Umi, a community organiser for KSM

There are many training programmes to increase our product quality. - Yayuk, a local community member who has participated in an Aloe Vera business programme

The interviewees describe how YPESB has provided comprehensive assistance to the local community members to conduct the business programmes. YPESB, moreover, keeps giving assistance to the members who have been successful in developing their business programmes. This process was successful, in the case of the few programmes where it was applied, in increasing the local community's capacity to have power and control over their own development programmes and ensure the sustainability of these programmes. This means that they can continue undertaking these businesses without support from the mining company when the mining operation has completed its contract and will not depend on the mining resources anymore.

\section{DISCUSSION}

\section{The Power Issues in the Mining's Community Development Implementation}

The research findings highlight several problems of power in the implementation of YOP and YPESB's community development programmes. First, the mining company intends to retain its power over the local communities in regards 
to economic resources, information and technology through the community development programmes. It can be shown from the tension between two different agendas of the mining company, which are the production/commercial framework (with its primary focus on profit) and development agenda, emerged in the implementation of its community development programmes. The company seems to have prioritised its own interests in achieving profits from its operation, rather than the interests of the local communities (many of whom are poor and marginalised) to obtain benefits from the mining operation, including from the community development programmes.

The production/commercial framework has dominated and influenced the way in which the mining company has been conducting its community development programmes, particularly in YOP's revolving fund programmes. The funds or grants from this programme are distributed by the mining company to "calm down" the protest actions from the local community who are against the mining company. The mining company assumed that these protest actions would threaten the mining operation, and would therefore hinder them in obtaining profits from its operation. In the research interviews, the local community members explained that this financial approach influenced the development of a money orientation and expectations of the local community. The people become used to seeing the mining company as the source of grants or money which were a form of charity or compensation from the mining operation. Participation in the community development programmes is negatively influenced upon by these characters.

The second issue is the mining company has failed to increase the capacity of the local community to have power in making decisions related to their own development programmes which should be achieved by encouraging them to participate in decision making processes. While it can be understood that the mining company puts profits first, this goes against a people-centred approach to development which puts people as the subject and primary resource who conduct the development processes, and seeks to achieve the fulfilment of its material and spiritual well-being as the end or outcome of the development processes (Korten and Carner 1984). In line with this people oriented notion, some scholars point out that these outcomes can be achieved if community development practitioners focus on increasing the capacity of local community members, so they have power and control in designing, conducting and identifying problems that occur and finding the solutions to these problems; this is known as the empowerment process (Bhattacharyya 2004; Kenny 2006; Swanepoel dan De Beer 2006). 
In the case of the revolving fund programme, this can theoretically empower the local communities. By adopting a bottom-up approach, this programme accommodates the local community's interests in having control and power to design and undertake their own development programmes. However, this study found that this approach, in many YOP's development programmes has failed to empower the community due to several reasons. First, YOP has not yet put much effort to increase capacity and skills of the local communities to undertake their development programmes. The lack of these skills has meant that many local members, due to their subsistence culture, lack of education and issues of poverty, tend to spend their loans on fulfilling their basic needs; this then leads them to have debt problems in YOP's revolving fund programme.

Second, the mining company has used its power over the local communities by distributing YOP's revolving fund programme as a "bribe" to secure its interest to maximise profits from the mining operation. The community participation in YOP's revolving fund programme can be included in tokenism level of Arnstein's ladder of citizen participation. YOP has provided a mechanism by which the local community can choose their own development programmes through a revolving fund programme. However, the rights to make decision in regard to whom will obtain the fund is fully on YOP and the mining company's hands, as illustrated by an interviewee as follows:

We do not have any standard to select community groups who will receive a loan from YOP... some of the local community members who have received the revolving fund programme are the community groups who protest against the mining company by doing demonstrations. Arif, a Community Development division staff member

The interviewee describes that YOP has not stipulated any standard that can be followed by the local communities in order to obtain the loans from its revolving fund programme. All the decisions related to the application evaluation are made by YOP and the company. Based on the above discussion, it is clear that the local communities have become the object rather than the subject in the community development programmes. This is illustrated by the fact that the local communities have not yet become the main role-player in the implementation of the mining company's community development programmes. This means that, as Swanepoel dan De Beer (2006) state, there are problems with the local community participation. 


\section{How to Distribute Power to the Local Community? Reinventing Arnstein's Work}

Previous discussions depict the problem of power which has given rise to unintended impacts of community development programmes which are dependency, resistance and disempowerment of the local community. The local communities have realised these different outcomes, as illustrated by an interviewee as follows:

If we want a charity programme or money we can just ask YOP, but if we require a development or empowerment programme we should make a proposal to YPESB. - Umi, a community organiser for KSM

The above interview excerpt illustrates the conclusion which has been made by the local community members related to the different outcomes of YOP and YPESB's programmes. They have jumped to the conclusion which given them several options whether they only want to get money or empowerment objective from the company's community development programmes.

This study proposes a model or mechanism of the way in which the power could be distributed by YPESB to or shared with the local community. This model has led to the empowering community outcomes in its local business programmes. YPESB has played its role as a facilitator who has the power to increase the capacity and skills of the local communities to undertake their business programmes. YPESB has involved the local communities in the decision-making process, including: choosing the kinds of business programmes which have been established by YPESB; informing them of problems in conducting these businesses; and assisting them in finding solutions to these programmes. For instance, YPESB introduces local banks to the local community, and they have become familiar with dealing with these banks if they need funds to conduct their businesses. This has increased the power of the local community to control and conduct their own business programmes.

The mining company needs to consider applying across all of its community development programmes the same strategies as used in YPESB, such as providing ongoing intervention or assistance to the local communities based on their participation in the community development programmes. Rowlands (1995) states that in practice, the process of empowerment involves forms of group work, which require the role of outside professionals who become helpers and facilitators. This strategy, however, will present challenges to the mining company as community development practitioners due to the fact 
that the participatory development requires the mining company to surrender some power or control to the local communities to determine their own development programmes. The mining company already has power over the local communities in terms of economic resources, knowledge and technology (Muthuri 2007; Newell 2005). By using this power, the mining company has the capacity to dominate the ongoing intervention process with the local communities. However, this results in disempowerment or dependency of the local communities on the mining company. The mining company needs to consider employing strategies which can align its power orientation with the participatory development principle. Similar to YPESB's role, the mining company can become a facilitator of the local communities in finding solutions to the problems emerging in the implementation of community development programmes. The local communities should be involved in decision-making by choosing and determining the solutions to the problems.

The model of community participation which has been employed by YPESB should be put in the highest level of participation in Arnstein's ladder of citizen participation. In this model, the local communities have taken control to manage their own development programmes. However, first, YPESB has to increase capacity of the local communities to have skill in conducting these programmes. YPESB has given ongoing assistance to conduct programmes and conducted two ways communication with the local communities to seek solutions to the various problems until they can conduct development programmes by themselves. By giving an example in Model Cities, Arsntein (1969) states that people simply demand the degree of power (or control) which guarantees that participants can govern a programme or an institution, be in full charge of policy and managerial aspects, and be able to negotiate the conditions under which "outsiders" may change them. YPSEB has given this kind of control by distributing power to the local communities to have a managerial skill in conducting the community development programmes.

\section{CONCLUSION}

This study shows that the issue of power has hampered the mining company to embrace the community empowerment objective of its community development programmes. This objective requires the distribution of power to powerless people or communities. Based on conventional theory of power, the process of empowerment seems unachievable because the power holders 
should give some of their power to the communities. This can be illustrated in how the mining company as a community development practitioner, in its powerful position, undertakes its development programmes. The mining company, which already has "power over" the local communities in terms of economic resources, information and technology tends to retain this power by concealing it in the community development programmes. The mining company has employed these programmes to placate the protest actions of the local communities to secure its operation. This has meant that the company has prioritised its own interests in achieving profits from its operation, rather than to attain the community empowerment objective of its development programmes. As consequences, this has resulted in several unintended impacts including the financial dependency and resistance of the local communities on the mining company.

Paradoxically, this study also depicts that the mining company in a very limited way has empowered the local community through one of its foundations. The mining company has utilised an ongoing and comprehensive model or mechanism by which the power can be distributed to or shared with the local communities. The adoption of this model has succeeded to increase the capacity and skills of the local communities to participate in the company's development programmes. This capacity and skills include the community capability to make decisions in determining, conducting and finding solutions in regard to their own development programmes.

This study illustrates a small instance that demystifying power is possible in the community development practices. Distribution of power as a way to increase community participation in decision making processes to achieve empowerment objective is justifiable. Further empirical studies in different levels, issues and contexts to build theoretical understanding related to models or mechanisms in how to distribute power in conducting development programmes are warranted.

\section{ACKNOWLEDGEMENTS}

Our great appreciation goes to the Indonesian government and Direktorat Jenderal Pendidikan Tinggi (DIKTI) which provided a scholarship to the first author in studying and learning about a different academic environment overseas. 


\section{NOTES}

* Anif Fatma Chawa is an associate professor as well as chairperson at Department of Sociology, Faculty of Social and Political Sciences, Universitas Brawijaya (FISIPUB), Indonesia. She teaches the undergraduate and postgraduate programmes at her faculty. She has supervised more than 40 undergraduate students of Sociology Study Programme, and graduate students from various study programmes including Sociology, Politic and Poverty Studies. She graduated from the Department of Sociology of Faculty of Social and Political Sciences, Universitas Airlangga (1997) and graduate programme in Sociology (2003) Universitas Gadjah Mada (UGM). She obtained her doctorate degree in Community Development at College of Arts, Victoria University (VU) in 2014. She has conducted research studies concerning on community development practices and presented papers in several workshops related to Corporate Social Responsibility (CSR) and Community Development conferences as well as published them. Her first research study was the implementation of community development programmes in a mining industry located in Sumbawa Island for her doctoral thesis in Victoria University, Melbourne, Australia. She has been part of the consultant team for PT. Bentoel (a giant corporate in Malang) in conducting its CSR programmes. She also studies women empowerment issues, especially in informal sectors. She employs sociological theories in various perspectives, both micro and macro perspectives in conducting her research studies and community services primarily focusing on the implementation of community development programmes.

** Marty Grace was professor of Social Work at Victoria University, Melbourne Australia. She was also senior researcher and Head of Social Work. Her focus has been on homelessness and women's creativity and has been conducting a lot of research in these areas. The research findings have been published in several books and journals. She was enthusiastic about supervising research students and supporting them to publish findings in international journals. She has retired, but still supervises some research students, and has been appointed Emeritus Professor by Victoria University. Now, she is enjoying her hobbies on sewing and gardening with family and friends.

\section{REFERENCES}

Arnstein, S. 1969. A ladder of citizen participation. AIP Journal 35: 216-244, https://doi.org/10.1080/01944366908977225.

BAPPEDA Kabupaten Sumbawa Barat. 2008. Sistem informasi profil daerah Kabupaten Sumbawa Barat. BAPPEDA Kabupaten Sumbawa Barat, Pemerintah Kabupaten Sumbawa Barat. http://perpustakaan.bappenas.go.id/lontar/upac/ themes/bappenas4/template (accessed 12 February 2012).

Bendell, J. 2005. In whose name? The accountability of corporate social responsibility. Development in Practice 15 (3-4): 362-374, https://doi.org/10. 1080/09614520500075813. 
Berner, E. and Phillips, B. 2005. Left to their own devices? Community self-help between alternative development and neo-liberalism. Community Development Journal 40 (1): 17-29, https://doi.org/10.1093/cdj/bsi003.

Bhattacharyya, J. 2004. Theorizing community development. Journal of the Community Development Society 34 (2), https://doi.org/10.1080/15575330409490110.

Blowfield, M. 2004. CSR and development: Is business appropriating global justice? Development 47: 61-68, https://doi.org/10.1057/palgrave.development.1100068.

Chambers, R. 1993. Challenging the professions: Frontiers for rural development. London: Intermediate Technology Publication.

Cragg, G. 2002. Reasoning about responsibilities: Mining company managers on what stakeholders are owed. Journal of Business Ethics 39 (3): 319-35.

DuBois, M. 1991. The governance of the Third World: A Foucauldian perspective on power relations in development. Alternatives 16 (1): 1-29.

Fook, J. 2012. Social work: A critical approach to practice. London: SAGE Publications.

Fox, T. 2004. Corporate social responsibility and development: In quest of an agenda. Development 47 (3): 30-35, https://10.1057/palgrave.development.1100064.

Hamann, R. 2003. Mining companies' role in sustainable development: The "why" and "how" of corporate social responsibility from a business perspective. Development Southern Africa 20 (2): 237-254, https://doi.org/10.1080/03768350302957.

Harcourt, W. 2004. Editorial: Is CSR rewriting development? Development 47: 1-2, https://doi.org/10.1057/palgrave.development.1100072.

Hustedde, R. J. and Ganowicz, J. 2002. The basics: What's essential about theory for community development practice. Journal of the Community Development Society 33 (1): 1-19, https://doi.org/10.1080/15575330209490139.

Ife, J. 2013. Community development in an uncertain world: Vision, analysis and practice. Port Melbourne, Victoria: Cambridge University Press.

Kapelus, P. 2002. Mining, corporate social responsibility and the "community": The case of Rio Tinto, Richards Bay Minerals and the Mbonambi. Journal of Business Ethics 39 (3): 275-296, https://doi.org/10.1023/A:1016570929359.

Kemp, D. 2010. Mining and community development: Problems and possibilities of locallevel practice. Community Development Journal 45 (2): 198-218, https://doi. org $/ 10.1093 / \mathrm{cdj} / \mathrm{bsp} 006$.

Kenny, S. 2006. Developing communities: For the future. Melbourne: Thomson.

Korsah-Brown, D. 2002. Environment, human rights and mining conflict in Ghana. In Human rights and the environment: Conflicts and norms in a globalizing world, ed. Zarsky, L., 79-95. London: Earthscan Publications.

Korten, D. C. 1987. Community management: Asian experience and perspectives. West Hartford, CT: Kumarian Press.

Korten, D. C. and Carner, G. 1984. Planning framework for people-centered development. In People centered development, eds. Korten, D. C. and Klauss, R., 201-209. West Hartford, CT: Kumarian Press.

Larmer, B. 2009. The real price of gold. National Geographic Magazine, http://ngm. nationalgeographic.com/print/2009/01/gold/larmer-text (accessed 15 January 2012). 
Larrison, C. R. 2002. A comparison of top-down and bottom-up community development interventions in rural Mexico: Practical and theoretical implications for community development programs. New York: Edwin Mellen Press.

Leisinger, K. 2007. Capitalism with a human face: The UN global compact. Journal of Corporate Citizenship 28: 113-32.

Leith, D. 1993. The politics of power: Freeport in Suharto's Indonesia. Honolulu: University of Hawaii Press.

Macdonald, L. 1995. NGOs and the problematic discourse of participation. In Debating development discourse: Institutional and popular perspective, eds. Moore, D. B. and Schmitz, G. J. London: Macmillan Press.

MacKay, F. 2002. Mining in Suriname: Multinationals, the state and the Maroon community of Nieuw Koffiekamp. In Human rights and the environment: Conflict and norms in a globalizing world, ed. Zarsky, L., 57-78. London: Earthscan Publication.

Martin, S. and Newell, K. 2008. Mining ombudsman case report: Rapu Rapu polymetallic mine. Carlton: Oxfam Australia, https://doi.org/10.5204/ijcjsd.v2i1.90.

McArdle, J. 1989. Community development tools of trade. Community Quarterly 16: 4754.

Mining Company. 2005. Pemberdayaan masyarakat: Yayasan Olat Perigi. Kabupaten Sumbawa Barat: Yayasan Olat Perigi.

Moon, J. 2002. The social responsibility of business and new governance. Government and Opposition 37 (3): 385-408, https://doi.org/10.1111/1477-7053.00106.

Muthuri, J. N. 2007. Participation and accountability in corporate community involvement programs: A research agenda. Community Development Journal 43: 177-193, https://doi.org/10.1093/cdj/bs1053.

Newell, P. 2005. Citizenship, accountability and community: The limits of the CSR agenda. International Affairs 81 (3): 541-557, https://doi.org/10.1111/j.14682346.2005.00468.x.

Newell, P. and Frynas, J. G. 2007. Beyond CSR? Business, poverty and social justice: An introduction. Third World Quarterly 28 (4): 669-681, https://doi.org/ 10.1080/01436590701336507.

Onyx, J. and Benton, P. 1995. Empowerment and ageing: Toward honoured places for crones and sages. In Community empowerment: A reader in participation and development, eds. Craig, G. and Mayo, M., 46-58. New Jersey: Zed Books.

Robinson, K. M. 1986. Stepchildren of progress: The political economy of development in an Indonesian mining town. Albany, New York: State University of New York Press.

Rosenthal, E. 2002. Conflicts over transnational oil and gas development off Sakhalin Island in the Russian Far East: A David and Goliath tale. In Human rights and the environment: Conflicts and norms in a globalizing world, ed. Zarsky, L., 96-119. London: Earthscan Publications.

Rowlands, J. 1995. Empowerment examined. Development in Practice 5 (2): 101-107, https://doi.org/10.1080/0961452951000157074.

Scott, J. C. 1985. Weapons of the weak: Everyday forms of peasant resistance. New Haven and London: Yale University Press.

Setiawan, D. and Ginting, P. 2008. Mempertanyakan tanggung jawab sosial perusahaan. Jakarta: Wahana Lingkungan Hidup Indonesia (WALHI). 
Smart, B. 2002. Michael Foucault. London: Routledge.

Soelistijo, U. W. 2010. Dinamika Penanaman Modal Asing (PMA) bidang pertambangan umum di Indonesia. MIMBAR: Jurnal Sosial dan Pembangunan 27 (1), https://doi. org/10.29313/mimbar.v27i1.314.

Swanepoel, H. and De Beer, F. 2000. Introduction to development studies. Cape Town: Oxford University Press.

2006. Community development: Breaking the cycle of poverty. Lansdowne, South Africa: Juta.

Tahajuddin, U. et al. 2006. Peran community development perusahaan industri dan dampaknya pada masyarakat sekitarnya: Studi kasus di PT. Chevron Pacific Indonesia, Riau. Jakarta: LIPI Press.

Utting, P. 2007. CSR and equality. Third World Quarterly 28 (4): 697-712, https://doi. org/10.1080/01436590701336572.

Wartick, S. L. and Wood, D. J. 1998. International business and society. Oxford: Blackwell Business.

Welker, M. 2007. SEAP Bulletin: The rationality of corporate social responsibility in Indonesia. Cornell: Cornell University. 2009. Corporate security begins in the community: Mining, the corporate social responsibility industry, and environmental advocacy in Indonesia. Cultural Anthropology 24 (1): 142 - 179, https://doi.org/10.1111/j.1548-1360.2009.00029.x. 2012. The Green Revolution's ghost: Unruly subjects of participatory development in rural Indonesia. American Ethnologist 39 (2): 389-406, https://doi. org/10.1111/j.1548-1425.2012.01371.x.

Wood, D. J. 1994. Business and society. New York: Harper Collins.

Yakovleva, N. 2005. Corporate social responsibility in the mining industries. Hampshire: Ashgate. 